\title{
Quantifying the effect of surface covering materials on land surface temperature in urban areas utilizing Landsat imageries: An investigation of Kandy City, Sri Lanka
}

\author{
RJM Uduporuwa*1, L Manawadu ${ }^{2}$ \\ ${ }^{1}$ Department of Geography and Environmental Management Sabaragamuwa, University of Sri \\ Lanka \\ ${ }^{2}$ Department of Geography University of Colombo, Sri Lanka
}

\begin{abstract}
This paper attempts to investigate whether there is an effect of surface covering materials on land surface temperature in Kandy city, Sri Lanka by employing GIS and RS techniques. Measuring the change in built-up area, detecting the correspondent change in land surface temperature and identifying the correlation between surface covering materials and land surface temperature in temporal basis are the objectives of this paper. The paper utilizes Urban Index (UI), Land Surface Temperature (LST) and simple linear regression technique to achieve the objectives. Landsat satellite images with moderate resolution in 1994, 2003, 2007 and 2015 obtained from the server of United State Geological Survey (USGS) were used. Results evidently illustrates that both surface covering materials and land surface temperature in the city have substantially increased during the last-twenty-year period. The mean temperature in the city has risen from by $5.83 \mathrm{C}^{0}$ degrees from $1994\left(23.78 \mathrm{C}^{0}\right)$ to $2015\left(29.61 \mathrm{C}^{0}\right)$. Simple linear regression analysis indicates that there is an obvious impact of increase in surface covering materials on the surface temperature rise in Kandy city.
\end{abstract}

Keywords: Kandy City, Urban Index, Land Surface Temperature, Correlation

\section{Introduction}

At present, urban growth has become an unavoidable phenomenon and brings both positive and negative impacts into the world. Urban growth undeniably expands the built-up area with different types of surface covering materials which are buildings and non-building structures such as roads/streets and all other man-made structures (Masakorala and Dayawansa,2015). Most of the urban areas especially in developing countries are growing in a spontaneous manner adding the different types of surface materials causing many environmental issues. It is found by research as of today that the most adverse impact of increasing surface materials in urban areas, is the rise of Land Surface Temperature (LST). This has been thoroughly emphasizing since last few decades because land surface temperature is fundamentally important to many aspects such as surface energy balance, urban climatology as well as an important indicator of both the greenhouse effect and the physics of land-surface processes at local through global scales. Therefore, it is much important to investigate whether there is an effect of artificial surface materials on land

* Corresponding Author

(D) https://orcid.org/0000-0002-4672-5344

Email address: manohariuduporuwa@mail.com. lasangeo@gmail.com

Received 9 March 2019; Received in revised form 24 June 2019; Accepted 27 June 2019

DOI: http://doi.org/10.4038/bhumi.v7i1.50 
surface temperature in urban areas for the future development of cities. (Jayaweera and Rajapaksha,2016).

Retrieval of built-up area which covers urban type of surface materials and land surface temperature on temporal basis in an urban area from satellite imageries can give a precise picture of change occurred in built-up area and thermal environment in that city. In this regard, application of geo-spatial techniques based on temporal basis remotely sensed imageries is very effective method to capture the change in surface covering materials and the surface temperature in a city.

\section{Methods \& Materials}

\subsection{Study Area}

This paper focuses on the change in land surface temperature in Kandy city (Figure 1), Sri Lanka which is one of world heritage cities in response to its areal expansion over last twenty-year period based on temporal basis Landsat data. The city is situated in a valley bottom surrounded by green hill slopes and bounded by the river Mahawali on the North
East and West and South by the Hantane range. It has been the major urban center for the hill country of Sri Lanka during the last 600 years history since its establishment as the capital of the Kandyan Kingdom in the $15^{\text {th }}$ Century. It has been inscribed as a world heritage city by the United Nations Educational, Scientific and Cultural Organization (UNESCO) in 1986 due to its cultural and historic value. Kandy city is the location for the Sacred Tooth Relic Temple and was shaped by different ruling periods of local and colonial during the last 600 years of period. However, the economic boom occurred in 1980 and 1990 associated with introduction of open economic policy into the country had created rapid constructions in the city without a proper plan. This has caused to expand the built-up area with different impervious surface materials removing its natural green areas. In this context, this study attempts to examine whether there is an effect of artificial surface materials on land surface temperature of Kandy city. Measuring change in built-up area, detecting change in land surface temperature and identifying association between built-up growth and land surface temperature are the objectives of this paper.

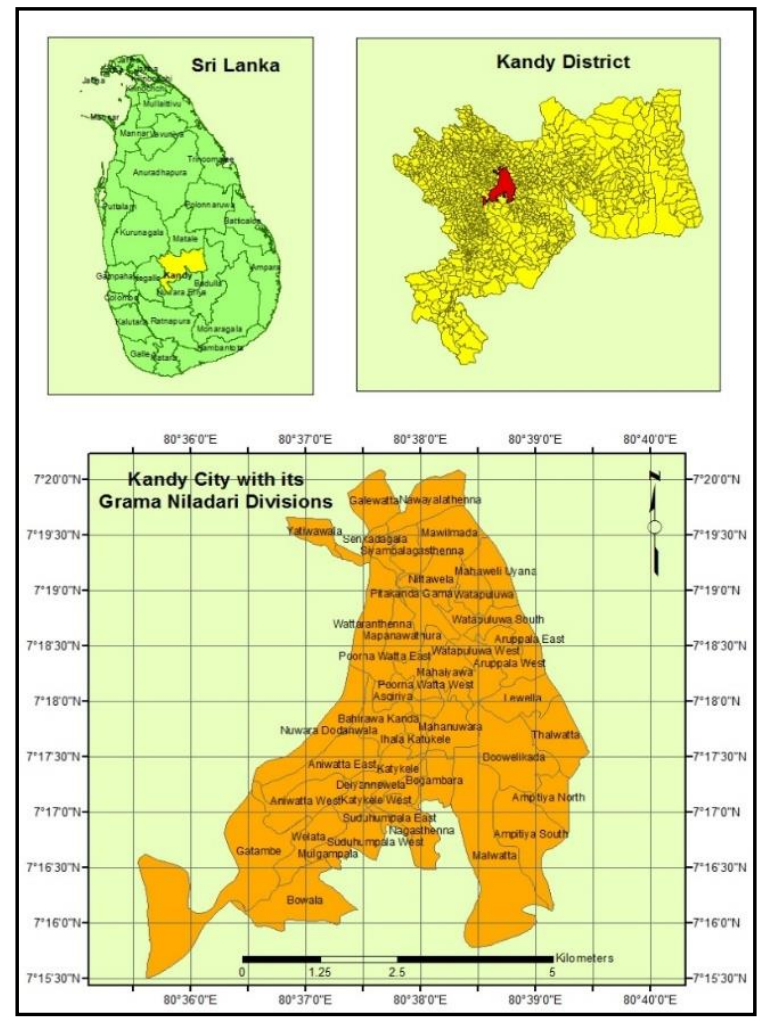

Figure 1: Kandy City 


\subsection{Methodology}

This paper uses Urban Index (UI), Land Surface Temperature (LST) and simple linear regression technique to achieve the above objectives. Depending on the data availability, Landsat satellite data with moderate resolution were obtained from USGS server (http://www.earthexplorer.usgs.gov). GIS (Geographical Information Systems) software was used for image processing and related mapping.

In this paper, built-up area is represented by UI (Equ. 1) which was used to estimate the builtup area in the city in 1994, 2003, 2007 and 2015. Built-up area covers all the artificial surface materials in the city including all types of buildings, streets and all the other man-made structures. UI values are represented as a ratio ranging from -1 to +1 . Positive values represent the built-up area while negative values represent none built-up area. Information of images used for UI retrieval is mentioned in Table 1 .

Equation: 1

$$
U I=((S W I R-N I R) /(\mathrm{SWIR}+\mathrm{NIR})
$$

Where;

UI = Urban Index

SWIR = Short Wave Infrared bands

NIR = Near Infrared band

This study uses the LST for the purpose of detecting change occurred in land surface temperature in the city during the last two decades. Surface temperature retrieval process has several steps. Conversion of DNs (Digital Numbers) to top-of-the atmosphere (ToA) radiance values which is the amount of energy that reaches the satellite sensor is the first step and this algorithm varies according to sensor types of Landsat images. Satellite stores information as radiance values but, it is converted to DNs when processed from $\mathrm{L}_{0}$ (raw data) to $\mathrm{L}_{1}$ product and therefore, it is essential to reconvert this information to its original format again for land surface temperature retrieval. Equation $2 \mathrm{a}$ and $2 \mathrm{~b}$ (http://landsat.usgs.gov) are involved to convert DNs to ToA of Landsat data. Equation $2 \mathrm{a}$ is involved with Landsat ETM+ and TM data while equation $2 b$ is involved with Landsat 8 OLT and TIRS data (http: //landsat.usgs.gov. 2015).

Equation: 2a

$$
\begin{gathered}
L_{\lambda}=\left(\left(L M A X_{\lambda}-L M I N_{\lambda}\right) /(\mathrm{QCALMAX}-\right. \\
\mathrm{QCALMIN}))\left((\mathrm{QCAL}-\mathrm{QCALMIN})+\operatorname{LMIN}_{\lambda}\right)
\end{gathered}
$$

Where;

\begin{tabular}{|c|c|c|c|c|c|c|c|c|}
\hline \multirow{3}{*}{$\begin{array}{l}\text { Acquisition } \\
\text { date }\end{array}$} & \multirow{3}{*}{$\begin{array}{l}\text { Satellite/ } \\
\text { Sensor }\end{array}$} & \multirow[t]{3}{*}{ Path } & \multirow[t]{3}{*}{ Row } & \multicolumn{2}{|c|}{ Wave Band } & \multirow{2}{*}{\multicolumn{2}{|c|}{$\begin{array}{l}\text { Spectral Range } \\
(\mathbf{n m})\end{array}$}} & \multirow{3}{*}{$\begin{array}{c}\text { Spatial } \\
\text { (pixel) } \\
\text { Resolution }\end{array}$} \\
\hline & & & & \multirow[t]{2}{*}{ SWIR } & \multirow[t]{2}{*}{ NIR } & & & \\
\hline & & & & & & SWIR & NIR & \\
\hline 1994.09 .11 & $\begin{array}{c}\text { Landsat } 5 \\
\text { TM L1T }\end{array}$ & 141 & 055 & 7 & 4 & $\begin{array}{l}2.09- \\
2.35\end{array}$ & $\begin{array}{l}0.76- \\
0.90\end{array}$ & 30 Meter \\
\hline 2003.01 .31 & $\begin{array}{l}\text { Landsat } 7 \\
\text { ETM+LIT }\end{array}$ & 141 & 055 & 7 & 4 & $\begin{array}{l}2.09- \\
2.35\end{array}$ & $\begin{array}{l}0.77- \\
0.90\end{array}$ & 30 Meter \\
\hline 2007.03 .23 & $\begin{array}{l}\text { Landsat } 5 \\
\text { TM LIT }\end{array}$ & 141 & 055 & 7 & 4 & $\begin{array}{l}2.09- \\
2.35\end{array}$ & $\begin{array}{l}0.76- \\
0.90\end{array}$ & 30 Meter \\
\hline 2015.03 .29 & $\begin{array}{l}\text { Landsat } 8 \\
\text { OLI TIRS }\end{array}$ & 141 & 055 & 7 & 5 & $\begin{array}{l}2.11- \\
2.29\end{array}$ & $\begin{array}{l}0.85- \\
0.88\end{array}$ & 30 Meter \\
\hline
\end{tabular}

$\mathrm{L} \lambda \quad=$ Cell value as radiance (at- sensor radiance)
$\mathrm{QCAL}=$ Digital Number (DN)
LMIN $=$ The spectral radiance that is scaled to
QCALMIN in watt $/ \mathrm{m} 2 *$ ster * $\mu \mathrm{m}$
$\mathrm{LMAX}_{\lambda}=$ The spectral radiance that is scaled to
QCALMAX in watt $/ \mathrm{m} 2 *$ ster * $\mu \mathrm{m}$
QCALMIN $=$ The minimum quantized calibrated pixel
value (typically 1 ) in DN
QCALMAX= The maximum quantized calibrated pixel
value (typically 255 ) in DN

Table 1: Information of Images used for Urban Index Retrieval in the Kandy City

Source: http://landsat.usgs.gov 
Equation: $2 b$

$$
L_{\lambda}=((M L)(Q c a l))+\mathrm{AL}
$$

Where;

$L \lambda=$ TOA spectral radiance $($ Watts $/(\mathrm{m} 2 * \operatorname{srad} *$ $\mu \mathrm{m}))$

$M L$ = Band-specific multiplicative rescaling factor from the metadata

Qcal $=$ The image (Band 10/ 11) (RADIANCE_MULT_BAND_x, where $\mathrm{x}$ is the band number)

At the second step, sensor radiance is in turn converted to the brightness temperatures $\left(T_{B}\right)$ of the viewed earth atmosphere system under an assumption of unity emissivity. This is also referred to as black body temperature and denotes a surface that absorbs all the electromagnetic radiation that reaches it. Following equation is used to covert ToA spectral radiance into brightness temperature (http: //landsat.usgs.gov. 2013).

Equation: 3

$$
\mathrm{T}_{\mathrm{B}}=\frac{\mathrm{K}_{2}}{\operatorname{In}\left[\frac{\mathrm{K}_{1} * \varepsilon}{\mathrm{L} \lambda}+1\right]}
$$

Where;

$\mathrm{TB}=$ Brightness temperature (in Kelvin)

$\mathrm{L} \lambda=$ TOA spectral radiance $($ Watts $/(\mathrm{m} 2 * \operatorname{srad} *$

$\mu \mathrm{m}))$

$\mathrm{K}_{1}=$ Band-specific thermal conversion constant from the metadata (K1_CONSTANT_BAND_x, where $\mathrm{x}$ is the thermal band number)

$\mathrm{K}_{2} \quad=$ Band-specific thermal conversion constant from the metadata (K2_CONSTANT_BAND_x, where $\mathrm{x}$ is the thermal band number

$\varepsilon \quad=$ Land Surface Emissivity (LSE)

Land surface emissivity is a quantification of the intrinsic ability of a surface to convert heat energy into above surface radiation and it depends on the physical properties of the surface and observation conditions (Sobrino, Raissouni, and Li, 2001). The emissivity of land, unlike that of oceans, can differ significantly from unity and vary with vegetation, surface moisture, roughness, and viewing angles (Salisbury \& D'Aria, 1992). There are three major methods: Land use classification-based emissivity method (CBEM) (Gillespie et al 1998; Peres \& Da Camara, 2005), NDVI-based emissivity method (NBEM) (Van de Griend \& Owe 1993; Momeni \& Saradjian, 2007) and day/night temperature-independent spectral-indices (TISI) based method (Wan \& Li, 1997; Becker \& Li 1990). NDVI-based emissivity method was later modified by Sobrino, JimenezMunoz, and Paolini (2004) is the well-known and accepted methods by the scientific community working in the thermal infrared today and this study also uses this method.Munoz, and Paolini (2004) is the wellknown and accepted methods by the scientific community working in the thermal infrared today and this study also uses this method.They have come up with three typical emissivity values in relation to different cases (Table 2). Calibration constant used for $T_{B}$ retrieval in equation 3 is shown in Table 3 .

Table 2. Typical Emissivity Values based on NDVI Method.

\begin{tabular}{|c|c|c|}
\hline $\begin{array}{c}\text { NDVI } \\
\text { Values }\end{array}$ & $\begin{array}{c}\text { Category/Class } \\
\text { of NDVI }\end{array}$ & $\begin{array}{c}\text { Typical } \\
\text { Constant } \\
\text { Values of } \\
\text { Emissivity }\end{array}$ \\
\hline NDVI $<0.2$ & Bare soil pixel & 0.995 \\
\hline NDVI $>0.5$ & $\begin{array}{c}\text { Fully vegetated } \\
\text { pixel }\end{array}$ & 0.99 \\
\hline 0.2 & $\begin{array}{c}\text { mixture of bare } \\
\text { soil and } \\
\leq \text { NDVI } \leq 0.5\end{array}$ & 0.986 \\
\hline
\end{tabular}

Source: Sobrino, Jimenez-Munoz, and Paolini , 2004

Table 3: Calibration Constant used for $\mathrm{T}_{\mathrm{B}}$ Retrieval with Equation 09

\begin{tabular}{|l|l|l|l|l|}
\hline & Lands & Landsat & \multicolumn{2}{|l|}{ Landsat 8 OLT } \\
at TM & \multirow{2}{*}{$\begin{array}{l}\text { ETM+ } \\
\text { (Band } \\
\text { (Band } \\
\text { 61) }\end{array}$} & 6) & $\begin{array}{l}\text { (Band } \\
\text { 10) }\end{array}$ & $\begin{array}{l}\text { (Band } \\
\text { 11) }\end{array}$ \\
\hline $\begin{array}{l}\mathrm{K} \\
1\end{array}$ & 607.76 & 666.09 & 774.89 & 480.89 \\
\hline $\mathrm{K}$ & 1260.56 & 1282.71 & 1321.08 & 1201.14 \\
\hline
\end{tabular}

Source: http://landsat.usgs.gov, 2015 
As the final stage brightness temperature which is in Kelvin in unit was converted to Celsius by using following equation http://landsat.usgs.gov. 2015).

Equation: 4

$$
T B=T B-273
$$

Where; $\mathrm{TB}=$ Brightness temperature (in Kelvin)
Table 5. Information of Simple Regression in Kandy City

Table 4: Information of Images used for LST Retrieval in Kandy City

\begin{tabular}{|c|c|c|c|c|c|c|}
\hline $\begin{array}{c}\text { Acquisition } \\
\text { date }\end{array}$ & $\begin{array}{c}\text { Satellite/ } \\
\text { Sensor }\end{array}$ & Path & Row & $\begin{array}{c}\text { Wave } \\
\text { Band }\end{array}$ & $\begin{array}{c}\text { Spectral } \\
\text { Range (nm) }\end{array}$ & $\begin{array}{c}\text { Spatial(pixel) } \\
\text { Resolution }\end{array}$ \\
\hline 1994.09 .11 & $\begin{array}{c}\text { Landsat 5 } \\
\text { TM L1T }\end{array}$ & 141 & 055 & 6 & 10.40 to 12.50 & 30 Meter \\
\hline 2003.01 .31 & $\begin{array}{c}\text { Landsat 7 } \\
\text { ETM+LIT }\end{array}$ & 141 & 055 & 6 & 10.40 to 12.50 & 30 Meter \\
\hline 2007.03 .23 & $\begin{array}{c}\text { Landsat 5 } \\
\text { TM LIT }\end{array}$ & 141 & 055 & 6 & 10.40 to 12.50 & 30 Meter \\
\hline 2015.03 .29 & $\begin{array}{c}\text { Landsat 8 } \\
\text { OLI TIRS }\end{array}$ & 141 & 055 & $\begin{array}{c}10 \\
\& 11\end{array}$ & 10.40 to 12.50 & 30 Meter \\
\hline
\end{tabular}

Source: http://landsat.usgs.gov, 2015

\begin{tabular}{|c|c|c|c|}
\hline $\begin{array}{c}\text { Independent } \\
\text { Variable (x) }\end{array}$ & $\begin{array}{c}\text { Dependent } \\
\text { Variable } \\
(\mathbf{y})\end{array}$ & Year & $\begin{array}{c}\text { No } \\
\text { of } \\
\text { Cells }\end{array}$ \\
\hline UI & NDVI & $1994,2003,2007,2015$ & 29210 \\
\hline UI & LST & $1994,2003,2007,2015$ & 29210 \\
\hline NDVI & LST & $1994,2003,2007,2015$ & 29210 \\
\hline
\end{tabular}

Objective three was achieved through a simple linear regression model which is generally used to find out correlation between two variables. Cell values of UI and LST (Table 5) were used for this purpose and was performed by using simple liner regression analysis available in Excel 2007. Following is the equation of the simple linear regression.

Equation: 5

$$
y=a+b x+e
$$

Where;

$\mathrm{y} \quad=$ Dependent variable

$\mathrm{x} \quad=$ Independent variable

e $\quad=$ an "error" term

$\mathrm{a}, \mathrm{b}=$ constants

Constant $\mathrm{a}$ and $\mathrm{b}$ represent the intercept and slop, respectively of the regression line.

\section{Results and Discussion}

\subsection{Change in Built-Up Area by Urban Index (UI)}

Colour images of UI with five categories are shown in Figure 2 while illustration drawn by using their statistics are shown in Figure 4. Plus pixel values represent built up lands and minus pixel values represent mix of built up, vegetation, water and bare lands. As Figure 2 and Figure 4 indicates all categories of UI have undergone a change positively and negatively during the last twenty-year period. Expansion of built up area is an essential result of urban growth and Kandy city also has expanded its built-up area substantially during the corresponding time period. 


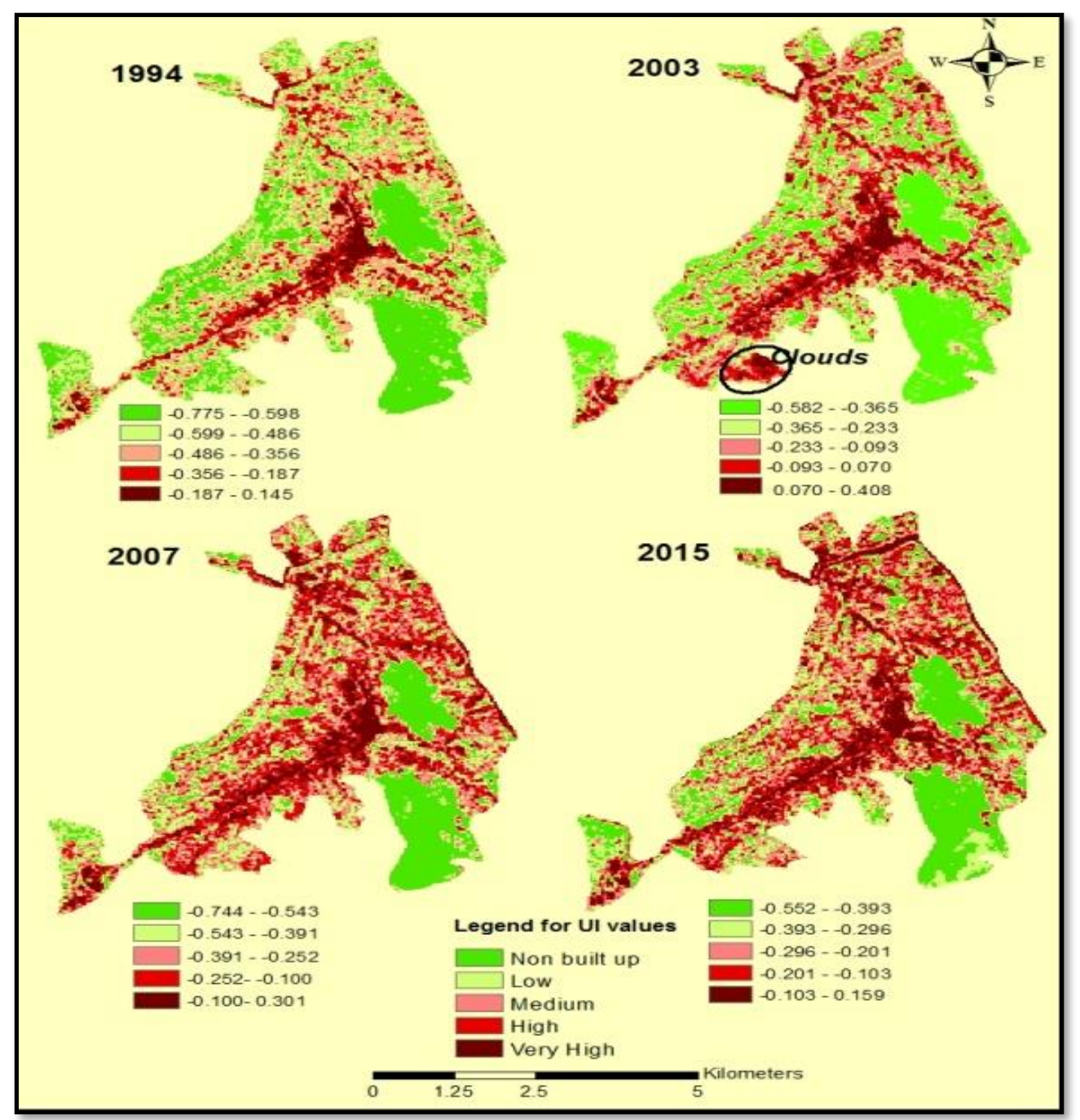

Figure 2: Spatio-Temporal Change in UI with Five Categories in Kandy City, 1994-2015

"Very high" category of UI which is the area of dense built-up has a remarkable continuous increase from 4.73 percent to 10.94 percent from the year 1994 to 2015 (Figure 3 and Figure 4). "High" and "medium" categories of UI also have increased at a higher rate from 1994 to 2015. "Low and "none built up" categories which represent the vegetation, have declined in corresponding time period. The most affected category observable in this regard, is the "None built up" category which represents the dense vegetation in the city. It has declined by 10 percent within a very short period from 2003(28 percent) to 2007 (18 percent) and is evident that during last twentyyear period, built-up area of the city has expanded considerably losing its vegetation cover by a substantial amount.

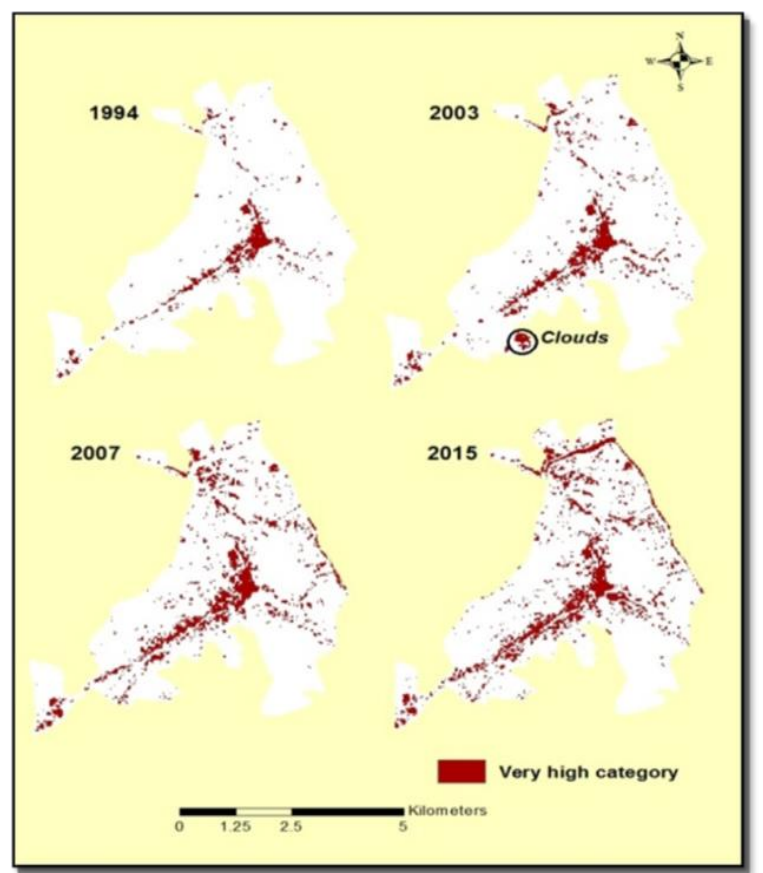

Figure 3: Spatio-Temporal Change in Very High Category of UI in Kandy City, 1994-2015 


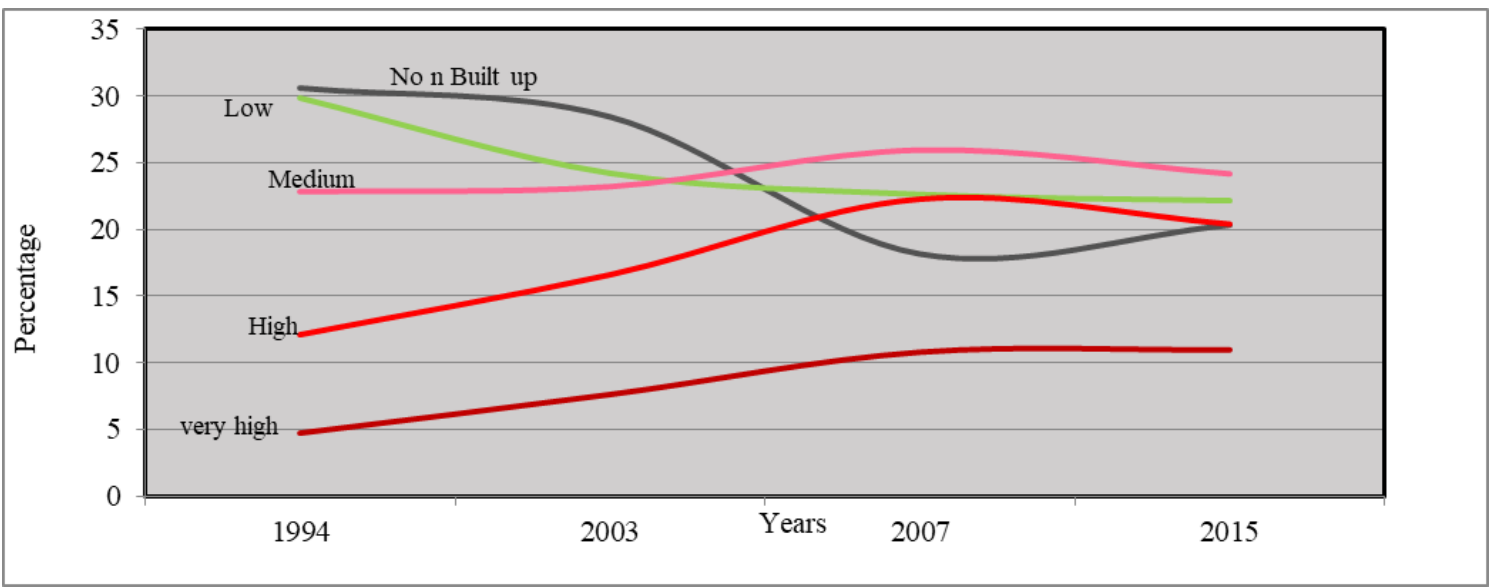

Figure 4: Trend of UI Categories in Corresponding Time Period (1994-2015)

\subsection{Change in Land Surface Temperature (LST)}

Output of image processing for detecting change in thermal environment in corresponding years in the city has been shown in Figure 5, Table 6 and Figure 6. Figure 5 gives a visual interpretation about how the surface temperature varies in different locations in the city and how temperature in corresponding years has changed with time. According to the figure there are noticeable spatial variations in LST representing different geographical characteristics of the city. Temperature values in the categories of "very low" and "low" are always associated with water bodies and forested areas. "Very low" values of temperature are observable in the Northern part of the Mahawali River with dense forest cover in river banks and forest tops of the Udawattakale and Doramadalawa reserved forest located in the South-Easter part of the city. Areas in the category of "low" temperature are lower parts of the Udawattakale and Doramadalawa reserved forest located in the South-Easter part of the city. Areas in the category of "low" temperature are lower parts of the Udawattakale and Doramadalawa reserved forest, Kandy lake which is located in the city center and forest strips located in Western and South-Western part of the city including Peradeniya botanical garden.
However, the images show that areas in the category of low temperature have become moderate temperature areas in 2015. Areas in medium temperature category which include the mean temperature are residential areas distributed in the periphery of the city.

Warmer areas in the city which represent the "high" (orange colour) and "very high" (red colour) pixel values are basically the city center areas, along the road lines running throughout the city and some areas in the Northern part of the city where the commercial activities have developed. The warmest areas (very high category) representing the highest temperature values lie along the main road which is Colombo-Kandy and city center areas. 


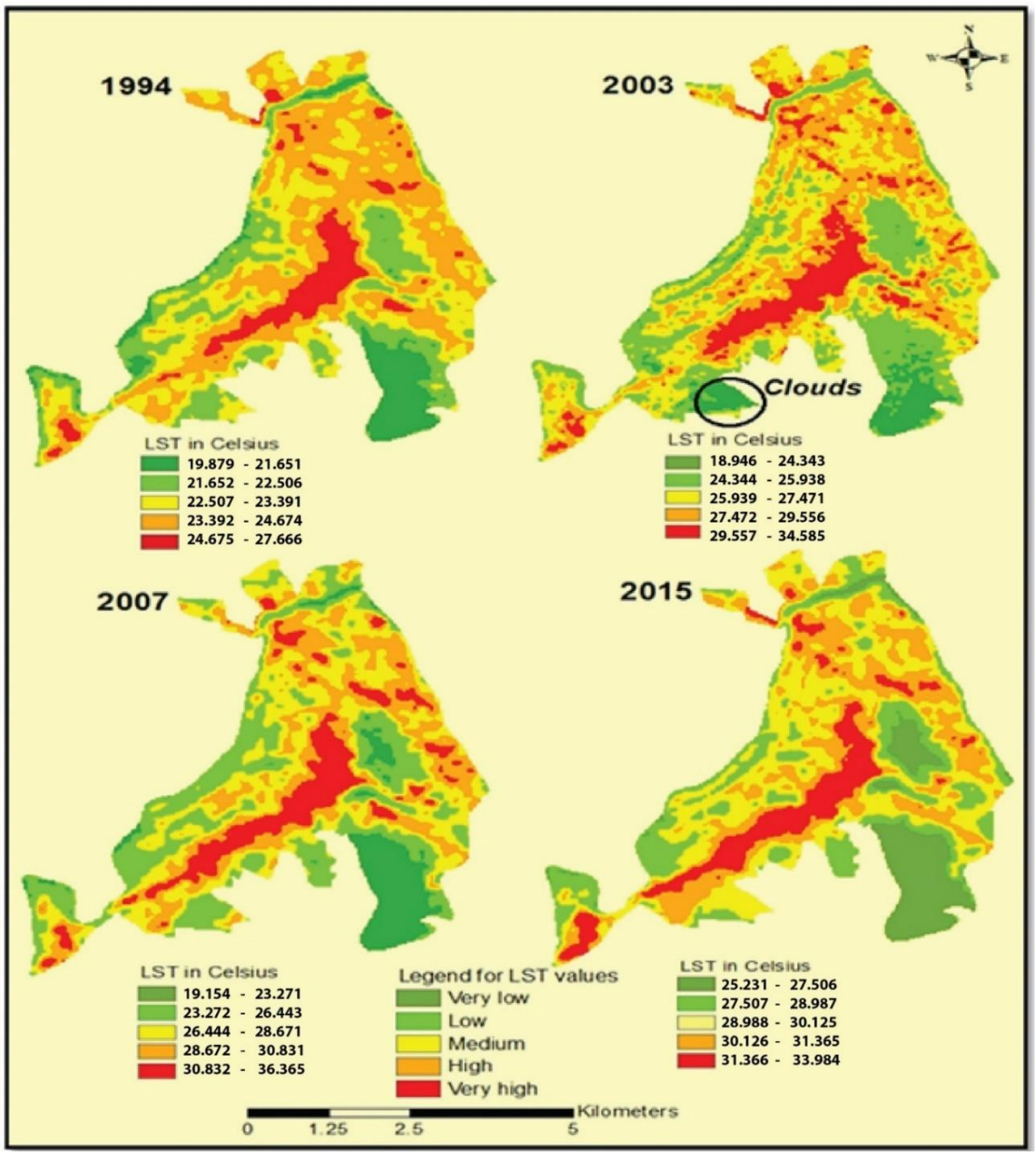

Figure 5: Spatio-Temporal Change in Land Surface Temperature (LST) in Kandy City, 1994-2015.

In addition, very high temperature patches are present in commercial areas in Northern part of the city.The city center areas are characterized by high population and housing densities, high vehicular traffic and an absence of vegetation. Areas in the category of "high temperature" lay down in surrounding areas of the warmest areas and Northern part of the city with the commercial development Considering the change in temperature levels through time basic observation is that all the categories have undergone a continuous temperature increase during last twenty year period. According to the statistics shown by the images both minimum and maximum temperature in the city have risen considerably (Table 6 and figure 6). Minimum temperature was low in the years of $1994\left(19.88 \mathrm{C}^{0}\right), 2003\left(18.95 \mathrm{C}^{0}\right)$ and even in $2007\left(19.15 \mathrm{C}^{0}\right)$ and its change has occurred after 2007. There is a sharp increase of minimum temperature within a short time period which is eight-year period from 2007 to 2015. It has increased from $19.15 \mathrm{C}^{0}$ in 2007 up to $25.23 \mathrm{C}^{0}$ in 2015 showing a temperature elevation of about $6.08 \mathrm{C}^{0}$. Maximum temperature also has an increase from the year 1994 to 2007. Its increase is sharp during the period from 1994 to 2007. In 1994 maximum 
temperature level was $27.68 \mathrm{C}^{0}$ and it has increased up to $34.59 \mathrm{C}^{0}$ in 2003 and further36.37 $\mathrm{C}^{0}$ in 2007 . However, there is a slight reduction in maximum temperature in 2015. All most all the temperature categories in 2015 have increased significantly compared with the temperature levels in 1994. This is apparently proved by the continuous increase in mean temperature from 1994 to 2015.
The result of simple linear regression analysis which was carried out based on pixel values of UI and LST has been given in Figure 7 and Table 7. Result illustrates that two phenomena are positively correlated even though there are fluctuations of degree of temperature within the corresponding years. Coefficient of correlation ( $\mathrm{R})$ always indicates there is a strong positive correlation (above 0.68) in each year between UI and NDVI

Table 6: Statistics of Temporal Change of Temperature in Kandy City, 1994-2015

\begin{tabular}{|c|c|c|c|c|}
\hline Years & $\begin{array}{c}\text { Minimum } \\
\text { LST }\left(\mathbf{C}^{\mathbf{0}}\right)\end{array}$ & $\begin{array}{c}\text { Maximum } \\
\text { LST }\left(\mathbf{C}^{\mathbf{0}}\right)\end{array}$ & $\begin{array}{c}\text { Mean } \\
\text { LST }\left(\mathbf{C}^{\mathbf{0}}\right)\end{array}$ & $\begin{array}{c}\text { SD } \\
\text { LST }\left(\mathbf{C}^{\mathbf{0}}\right)\end{array}$ \\
\hline 1994 & 20.81 & 28.00 & 24.95 & 1.55 \\
\hline 2003 & 18.95 & 34.59 & 26.85 & 2.00 \\
\hline 2007 & 19.15 & 36.37 & 27.21 & 2.99 \\
\hline 2015 & 25.23 & 33.98 & 29.54 & 1.56 \\
\hline
\end{tabular}

Source: Image Processing

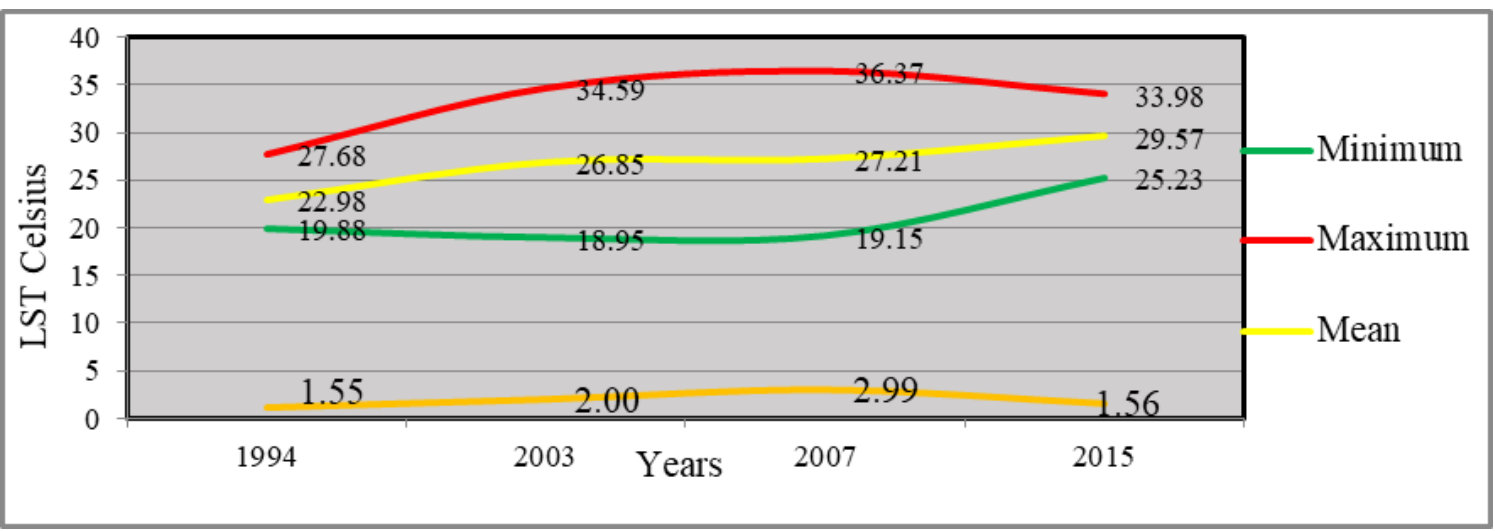

Figure 6: Temporal Change of LST in Kandy City, 1994-2015

\subsection{UI-LST Correlation}

According to the studies carried out on urban climate, artificial surface materials brought by urban growth was found to be a key determinant of temperature change in an area and these two phenomena are positively correlated each other. As explained above, both urban index and surface temperature during the corresponding time period have increased continuously.
Coefficient of determination ( $\mathrm{R}$ Squared) which is around 50 percent in the years of 2003 and 2015 and above it in the years of 1994 and 2007 indicates that there is a substantial impact of increase in surface materials on land surface temperature increase in the city. 

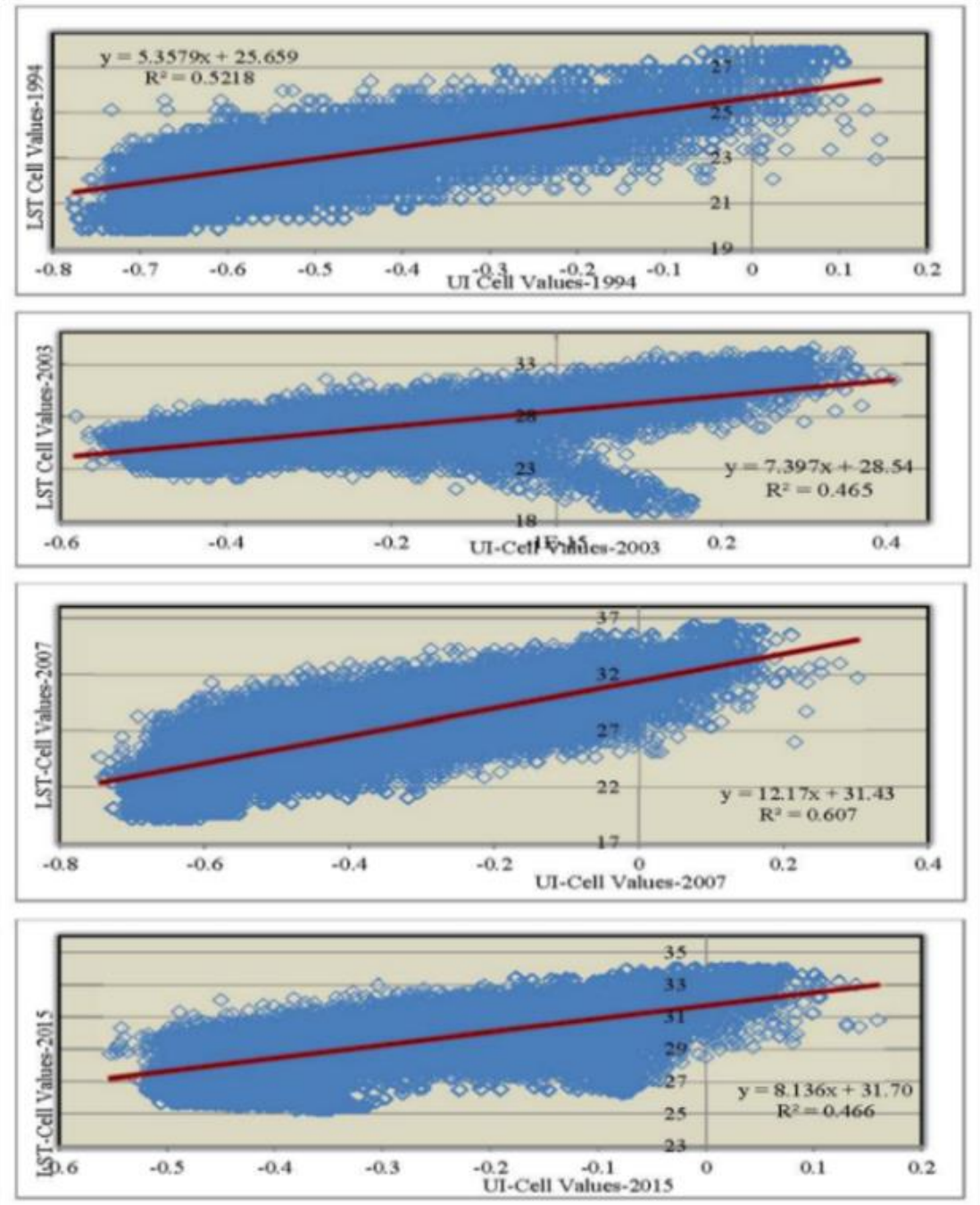

Figure 7: Scatter Plots of UI and LST in Kandy City, 1994-2015

Table 7: Statistical Correlation between UI and LST in Kandy City

\begin{tabular}{|c|c|c|c|c|}
\hline Year & $\begin{array}{c}\text { Multiple R=Coefficient } \\
\text { of correlation }\end{array}$ & $\begin{array}{c}\text { R Squared=coefficient of } \\
\text { determination }\end{array}$ & $\begin{array}{c}\text { P } \\
\text { Value }\end{array}$ & $\begin{array}{c}\text { Correction } \\
\text { type/degree }\end{array}$ \\
\hline 1994 & 0.72 & $0.52=\mathbf{5 2 \%}$ & 0 & $\begin{array}{c}\text { Strong positive } \\
\text { correlation }\end{array}$ \\
\hline 2003 & 0.68 & $0.47=\mathbf{4 7 \%}$ & 0 & $\begin{array}{c}\text { Strong positive } \\
\text { correlation }\end{array}$ \\
\hline 2007 & 0.78 & $0.61=\mathbf{6 1 \%}$ & 0 & $\begin{array}{c}\text { Strong positive } \\
\text { correlation }\end{array}$ \\
\hline 2015 & 0.68 & $0.47=\mathbf{4 7 \%}$ & 0 & $\begin{array}{c}\text { Strong positive } \\
\text { correlation }\end{array}$ \\
\hline
\end{tabular}

Source: Regression Analysis based on Cell Values of UI and LST in the Kandy City 


\section{Conclusion}

This study initially attempted to examine how the surface covering materials in Kandy city influences the land surface temperature in the city. As result shows both the built-up area and the land surface temperate in the city have noticeably increased from 1994 to 2015 . All the categories of UI have increased substantially and the mean temperature has risen from by $5.83 \mathrm{C}^{0}$ degree from $1994\left(23.78 \mathrm{C}^{0}\right)$ to 2015 $\left(29.61 C^{0}\right)$ in the city. Correlation analysis has clearly revealed that these two phenomena are positively correlated indicating increase in surface covering materials substantially influence the surface temperature rise in the city.

Dark surfaces generally absorb significantly more solar radiation which causes roads and buildings to heat more than rural areas during the day time. Materials commonly used in urban areas for pavements and roofs, such as concrete and asphalt, have significantly different thermal bulk properties and surface radiative properties.
This causes a change in the energy budget of the urban area, often leading to higher temperatures. Another major reason is the lack of evapotranspiration with a decreased amount of vegetation, cities also lose the shade and cooling effect of trees and increases amount of carbon dioxide. Temperature rise can produce secondary effects on local meteorology, including altering of local wind patterns, development of clouds, fog and the humidity and the rates of precipitation. If mitigation measures are not implemented in the city, in near future city will be an uncomfortable place for living and working and will increase the economic cost of living. Therefore, this study strongly recommends to take necessary steps to mitigate the problem of surface temperature rise in Kandy city.

\section{References}

Becker, F and Li, Z. L. (1990) Toward a local split window method over land surface. International Journal of Remote Sensing 3: 369-393. https://www.researchgate.net/publication/248976658. Accessed 23 September 2015

Gillespie, A., Rokugawa, S., Matsunaga, T., Cothern, J.S., Hook, S. and Kahle, A.B. (1998) A temperature and emissivity separation algorithm for advanced space borne thermal emission and reflection radiometer (ASTER) Images.

IEEE Transactions on Geosciences, Remote Sensing 36:1113-1126 https://ieeexplore.ieee.org/document/700995/metrics. Accessed 23 September 2015

http://www.earthexplorer.usgs.gov. Accessed 9 July 2015

http://landsat.usgs.gov. Accessed 9 July 2015

Jayaweera, N. and Rajapaksha, U., 2016. Diagnosing thermal behaviour of the administration block of the University of Colombo for retrofitting passive design strategies. Bhumi, The Planning Research Journal, 3(1),pp.25-41 
Masakorala, P.P. and Dayawansa, N.D.K., 2015. Spatio-temporal Analysis of Urbanization, Urban Growth and Urban Sprawl Since 1976-2011 in Kandy City and Surrounding Area using GIS and Remote Sensing. Bhumi, The Planning Research Journal, 4(2), pp.26-44.

Momeni, M. and Saradjian, M. (2007) Evaluating NDVI-based emissivities of MODIS bands 31 and 32 using emissivities derived by day/night LST algorithm. Remote Sensing of Environment 106:190-198. https://www.researchgate.net/publication/229362847. Accessed 6 September 2015

Peres, L. F. and Da Camara, C.C. (2005) Emissivity maps to retrieve Land-Surface Temperature from MSG/SEVIRI. IEEE Transactions on Geosciences and Remote Sensing 43 (8):1834-1844. https://www.researchgate.net/publication/220053227. Accessed 7 September 2015

Salisbury, J.W. and D'Aria, D.M. (1992) Emissivity of terrestrial materials in the 8-14 $\mu \mathrm{m}$ atmospheric window. Remote Sensing of Environment 42:83-106. https://www.sciencedirect.com/science/article/pii/003442579290092X Accessed 7 September 2015

Sobrino, J.A., Raissouni, N., and Li, Z.L. (2001) A comparative study of land surface emissivity retrieval from NOAA data. Remote Sensing of Environment 75:256-266. https://www.researchgate.net/publication/223915154. Accessed 18 September 2015

Sobrino, J.A., Jimenez-Munoz, J.C. and Paolini, L. (2004) Land surface temperature retrieval from Landsat 5 TM. Remote Sensing of Environment 90:434-440. https://www.sciencedirect.com/science/article/pii/S0034425704000574. Accessed 07 October 2015

Van de Griend, A., and Owe, M. (1993) On the relationship between thermal emissivity and the Normalized Difference Vegetation Index for natural surfaces. International Journal of Remote Sensing 14:1119-1131. https://www.researchgate.net/publication/23851967. Accessed 19 February 2016

Wan, Z., and Li, Z.L. (1997) A physics-based algorithm for retrieving land-surface emissivity and temperature from EOS/MODIS Data. IEEE Transaction on Geo science and Remote Sensing 35: 980-996. https://www.researchgate.net/publication/3201704. Accessed 13 February 2016 